\title{
МОВОЗНАВСТВО
}

УДК 811.161.2:81’367.625

DOI: 10.31475/fil.dys.2019.09.20

НАТАЛЯ ОСТРАТЮК, аспірантка (л. Кӥ̈в)

\section{Семантико-функціональна характеристика лексико-семантичного поля діеслів відчуття у сучасній українській літературній мові}

Статтю присвячено селантико-бункиіональній характеристиці лексико-селантичного поля дієслів відчуття у сучасній украӥнській літературній мові. Зазначено, шо позитивною семантичною ознакою дієслів відчуття як дієслів психічного стану є ознака процесуальності.

Аналіз семантичних значень засвідчив, шо дієслова відчуття не мають яскраво вираженої селантичної характеристики, в їх слисловій структурі частіше за все лістяться позитивні селантичні ознаки, крізь значення суб'єктності. У багатьох з них відсутня села активності, але пасивність злісту в них не маркована. Доведено, що дієслова відчуття вживаються в синтаксичних конструкиіях з прямим додаткол - назвою відчуттів або об'єктів відчуттів. У дієсловах відчуття додаткові селантичні колпоненти диналічність/статичність дій не проявляються достатньо послідовно.

У словотвірній парадиглі дієслів відчуття частотними є похідні зі значенням абстрактної діі. Дієслова відуття достатньо часто створюють акціональні парадигми, до яких входять дієслова з видовили значенняли, утворені за допологою префбіксів або суббіксів, $i$ лексел, що виражають додаткові селантичні модифбікацї.

Отже, більшість дієслів відчуття становлять активний фбонд лексики, що зуловлює законолірні взаєлодї, перехрещення дієслівних лексел. Безсулнівнил є взаєлозв'язок дієслів відчуття з лексикосемантичною групою дієслів сприйняття, а також з дієсловали бажання, емоційного переживання.

Ключові слова: дієслово, відчутmя, поле, селантика, лексела, сели.

Постановки проблели в загальному вигляді... $\mathrm{У}$ сучасній лінгвістиці, як українській, так і зарубіжній не втрачає актуальності 
дослідження семантичних особливостей дієслів як особливого складу слів, що характеризує ознаки предметів і їх відношень.

Аналіз досліджень $i$ публікаиій... У форматі ціеї проблеми працюють (I. Р. Вихованець, К. Г. Городенська, В. О. Горпинич, С. М. Дишлева, А. П. Загнітко, Н. Л. Іваницька, М. І. Степаненко, Н. М. Мединська та ін.). Але залишаються недостатньо описаними на лексико-семантичному та функціональному аспектах деякі групи дієслів, наприклад, дієслова відчуття, незважаючи на те, що вони відображають одну з найважливіших властивостей психічної діяльності людини. $\mathrm{y}$ зарубіжній лінгвістиці у порівняльному аспекті досліджувалися дієслова відчуття в російській і киргизькій мовах Т. С. Мусурманова, російській і таджицькій мовах - Д. К. Усманов, С. А. Файзіева.

Форлулювання иілей cmammi... Mета cmammi - дати загальну семантико-функціональну характеристику лексико-семантичного поля дієслів відчуття в сучасній українській літературній мові.

Виклад основного матеріалу... Позитивною семантичною ознакою дієслів відчуття як знаків психічного стану є ознака процесуальності. У науковій літературі їі інтерпретують як загальне значення дієслів, що презентують дію в динаміці їі перебігу в часі [1, с. 118]. Значення процесуальності характеризуе їх як дієслів доконаного, так i недоконаного виду. Стосовно дієслів стану загалом слушним $є$ зауваження Д. Грубора: «ці дієслова виражають стан, у якому хтось (щось) перебуває; в такому стані ніщо не виникае, не змінюеться, не переміщується, тільки час пливе мимо цьоо стану, указуючи на його тривалість» [3, с. 75].

Процесуальність як інваріантне значення «дієслівності» $€$ відмітною рисою діеслів відчуття, які не мають інших позитивних ознак і протиставлені іншим акціональним дієсловам.

Базовим словом усього аналізованого ЛСП і ЛСГ дієслова відчуття iз загальним семантичним значенням $е$ дієслово відчувати. За інтегральною семою 'почувати (відчувати) будь-яке відчуття, яке спричинено зовнішніми або внутрішніми стимулами' до ціеї групи входять синонімічні діеслівні лексеми: відчувати (відчути), чути, почувати (почути), учувати (учути), зазнавати (зазнати), полічати (помітити), слухати, сприйлати (сприйняти),почуватися (почутися) (розм.), уловлювати (уловляти, уловити) - 'відчувати, почувати що-небудь органами чуття’: Приєлно відчувати запах прілого листя і соснової слоли (С. Чорнобривець) [5, т. 1, с. 662]; Вона чула, як у грудях забилось серие, як ї̈ руки й ноги неначе охололи (Нечуй-Левицький) [5, т. 11, с. 385]; Почула [Сололія] вогкий холод, 


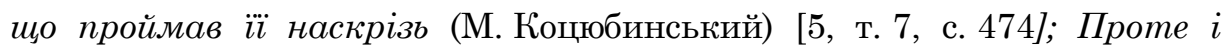
mут... - y пахощах кори, гілок так сало вчував [Василь] зогріте проленястил пилкол сония дихання весни (Я. Гримайло) [5, т. 10, с. 538]; Платон підставляв вітрові лице $і$ вловлював п'янкі запахи осіннього поля (М. Зарудний) [5, т. 10, с. 431]; Я теж зазнала великого розчарування в житті... (I. Вільде,) [5, т. 3, с. 128]; Надвечір Длитрик полічає, що йолу чогось мулько на сериі (М. Коцюбинський) [5, т. 7, с. 127]; Наслішкуваті слова сина сприйлає [мати] з тою доброю жіночою розсудливістю, яка властива спокійній, міиній натурі (М. Стельмах) [5, т. 9, с. 597]; Нал слухать тільки тут безсоннили ночали, як пахнуть дерева $і$ лопотить огонь... (В. Сосюра) [5, т. 9, с. 382]; Шралм уже й сал тоді почувсь, що треба дати собі пільгу (П. Куліш) [5, т. 7, с. 475].

Інші синонімічні ряди дієслів відчуття розрізнюються диференційними семами: передчувати (передчути), чути (розм.) 'наперед, заздалегідь відчувати те, що відбудеться, настане': Посилаю Вали свое останне оповідання $і$ передчуваю, шо будете лаяти лене за нього, бо я й сал себе лаю (М. Коцюбинський) [5, т. 6, с. 179]; Чую, чую, мої діти, що мені не животіти (Номис); Мар'ян не встиг увернутися від удару. Чуючи свою слерть, він охопив рукали голову, пригнувся (М. Стельмах) [5, т. 11, с. 385];охоплювати (охопити), перейняти (перейлати), оволодівати (оволодіти) - 'повністю оволодівати кимнебудь, захоплювати, заполонювати когось (про почуття, думки, враження)': Слуток все більше охоплював Данька (Олесь Гончар) [5, т. 5, с. 823]; Так сулно перейлало шось мою душу й мучило; так невиловно глибоко відчувала я свою салітність (О. Кобилянська) [5, т. 6, с. 187].

Діеслівними лексемами розрізняти (розрізнювати, розрізнити), розпізнавати (розпізнати), учути (тільки док.)передаеться значення 'сприймати, розпізнавати що-небудь органами відчуттів': Серие моє билося якось незвичайно, $i$ я старалася ловити вухол і розпізнавати його голос (I. Франко) [5, т. 8, с. 765]; Він розрізнявкожен звук, що даленів $і$ затихав над селол (А. Турчинська).

Значення 'мати здатність сприймати зовнішній світ органами чуттів' позначається неперехідними дієсловами відчувати (відчутu), почувати (тільки недок.): Потрібний був довгий шлях розвитку живой природи, щоб прийти до матерї, яка відууває $і$ мислить (Б. Теплов) [5, т. 1, с. 662]; Людина завжди так чи інакше діє, $i$ в ході своєї діяльності вона пізнає і почуває (Б. Теплов) [5, т. 7, с. 474].

Низка діеслів (відчуватися, почуватися, чутися) мають значення 'виявлятися, ставати помітним, відчутним': Виразновідчувався 
трепетний віддих оновленої зеллі (М. Коцюбинський) [5, т. 1, с. 662]; В неладі хатньолу почувається якась бурхлива нетерплячка (Леся Українка) [5, т. 7, с. 475]; Відділились від колони, поїхали мовчки поруч. Пилюкачулася в нічнолу повітрі, скрипіла на зубах (Олесь Гончар).

Каузативне значення 'діяти на людський організм у цілому або на окремий орган' позначається дієсловами дражнити, дратувати, подразнювати (подразнити), турбувати: Стікаючи вниз по каліниях, дражнила [вода] його слух своӥм солодкил дзюрчаннял (I. Франко) [5, т. 2, с. 405]; Наркотичний, важкий дух олеандрів та рути дратував ї̈ нерви (Нечуй-Левицький) [5, т. 2, с. 409].

Каузативне дієслово турбувати має значення 'мучити, бути відчутним (про біль, хворий орган і т. ін.)': Я чую біль, але ией біль уже не турбує (Ю. Яновський) [5, т. 10, с. 325].

Отже, 3 каузативними дієсловами можливі конструкції: Запаx дражнив ніздрі. - Біль турбував його.

В українській мові немає дієслів із значенням становлення відчуттів. Цей процес передається описово: Робиться чутливил до чогось. - Шкіра зробилася чутливою до подразнень.

Але значення 'викликати у кого-небудь певне відчуття', 'своєю дією, своїм впливом викликати у кого-небудь певні фрізичні відчуття (про вітер, холод)' позначаються каузативними діесловами перейняти (перейлати), пройлати (пройняти) (перен.): Розсліявся великий пан саркастичнил сліхол, що молоду дівчину перейняв морозол (О. Кобилянська) [5, т. 6, с. 187]; Погода була прекрасна. Тепле літнє повітряпройлиало, здавалося, все тіло (І. Франко).

Значення 'позбавляти гостроти сприйняття; притуплювати (зір, слух, пам'ять)' передаеться діесловами ослаблювати (ослабляти, ослабити): Не розуліючи того, шо ие втола і що ил втола ослабила пал'ять, він нарікав на себе, обзивав себе... нездарою (Г. Тютюнник) [5, т. 5, с. 770].

Дієслова залирати (завлерти) позначають 'переставати відчуватися, притуплятися, зникати (про відчуття)', наприклад: Давня зарозумілість, що мовби давно завлерла, віджила тепер наново в тій прибитій жіниі (О. Кобилянська) [5, т. 3, с. 53].

Аналіз семантичних значень засвідчив, що дієслова відчуття не мають яскраво вираженої семантичної характеристики, в їх смисловій структурі частіше не містяться позитивні семантичні ознаки, крім значення суб'єктності. У багатьох із них відсутня сема активності, але пасивність змісту в них не маркована. В українській мові формальним вираженням пасиву може бути постфікс -ся: чутися, почуватися, 
відчуватися; Пилюка чулася в нічному повітрі, скрипіла на зубах (О. Гончар) [5, т. 11, с. 386]; В неладi хатньому почуваеться якась бурхлива нетерплячка (Леся Українка) [5, т. 7, с. 475].

Дієслова відчуття утворюють пасивні форми дієвідмінюваної парадигми та пасивні дієприкметники i дієприслівники: біль відчувається, музика чуетьсл, почута пісня, побачене небо; В хаті почувався дух застояного повітря(О. Копиленко) [5, т. 7, с. 475]; Мати, як тінь, була невідступно з нил, перейлмючись його тривогали й болями (С. Журахович) [5, т. 6, с. 188].

Діеслова відчуття вживаються в синтаксичних конструкціях 3 прямим додатком - назвою відчуттів або об'єктів відчуттів: Він відчуває прохолоду. - Я розпізнав його голос. - Вона почула холод. Око розпізнавало всі фборли природи. - Вухо вловило шул. Можливі пасивні конструкції: Усіла відчувався холод. - Почувалася сирість. Він відчув пекучий біль = Біль обпік його.

Також можливі конструкції без додатка: Важкил та гіркил ярлол стало їй ї̈ життя. Вона не знала, як з його [нього] викрутитись, до того сала політила, що з нею діється щось-то неабияке (Панас Мирний) [5, т. 7, с. 127].

Деякі 3 дієслів відчуття вживаються в безособових конструкціях: Ціле літо пройлало якоюсь дивною студінню, немовби обкладав його хтось якоюсь мокрою, заболоченою шлатою (Л. Мартович).

Діеслова відчуття можуть уживатися образно: Серце почуло якесь лихо(Панас Мирний); Катерина... взяла в руку галузку яблуні, що набубнявіла, почувши весну (С. Чорнобривець) [5, т. 7, с. 474]; Ha солониях рослини майже завжди відчувають гостру нестачу води(Наука і життя) [5, т. 1, с. 662]; Чорні гори залляли долини, як велетенська отара. Вони вікують у такій тиші, що чують навіть дихання худоби (М. Коцюбинський); Про що зітха вітер? Що чують тулани. Коли гай зелений иілують-милують? (П. Тичина) [5, т. 11, c. 385].

Активні дієслова відчуття, уживані у цільовому значенні (тобто у сполученні з суб'єктом - істотою абопредметом, що визиває певне відчуття) - мають повну видову парадигму (доконаний і недоконаний види): почувати - почути: Кіньпочував кріпку дідову руку. Кіньпочув кріпку дідову руку; пригнічувати - пригнітити: Павло пішов по алеї, $і$ йолу здавалось, ніби гілля в гущавині пригнічує його зверху до зеллі (Нечуй-Левицький) [5, т. 7, с. 592].

Серед дієслів відчуття поширені «дефектні» у видовому відношенні діеслова: чути, віщувати, дурланити, бачити, дивитися, слідкувати, різати, пекти та ін.: Серие в неї якось чудно заколотилось, лов щось 
недобре вішувало(Нечуй-Левицький) [5, т. 1, с. 693]; Туя дурланить свойл запахол, аж голова чуланіе (Олесь Гончар) [5, т. 2, с. 439].

У дієсловах відчуття додаткові семантичні компоненти 'динамічність / статичність дії' не проявляються достатньо послідовно. Сферою дії семи динамічності є активні дієслова (відчувати, чути, боліти, нюхати, подразнювати і т. ін.), сферу дії маркованої статичності відчуття утворюють прикметники (відчутний, чутний, болісний, пахучий, нудотний, нудний, болячий і т. ін.), які передають характеристики предмета, «відносно незалежні від часу» [2], слова категорії стану (ллосно, нудно, видно, боляче тощо), прислівники (чутно, відчутно, нудотно, боляче тощо).

Т. А. Кільдібекова 3 цього приводу слушно зауважує: «... варіативність мовних засобів мінімальна в тій сфрері, що має "відбивну" природу, тобто в тій частині граматичних категорій, яка безпосередньо передає відношення явищ дійсності» [4, с. 59]. Саме тому дієслова відчуття, що мають розмиті граматичні та семантичні характеристики, активно взаємодіють із іншими мовними засобами вираження певного змісту, пор.: Він почув біль. - Йолу боляче; Від солодких пахощів квітів ллоїть вас. - Вал млосно від солодких пахощів квітів. Отже, синтагматичне варіювання підвищуеться, тому що відчуття може виражатися різними частинами мови.

Дериваційні можливості дієслів відчуття в значній мірі послаблено. Незважаючи на те, що в їх словотвірних парадигмах здійснюеться реалізація різноманітних актантів (суб'єкт, інструмент, об'єкт, засіб, місце, кількість) похідні утворюються менш послідовно, ніж у діеслів інших лексико-семантичних полів (руху, діяльності, переміщення тощо), тобто мають спорадичний характер.

У словотвірній парадигмі дієслів відчуття частотними е похідні зі значення абстрактної дії (відчувати - відчуття, почувати - почуття, чути - чуття, сприйлати - сприйлання, сприйняти - сприйняття тощо). Інші типи похідних зустрічаються рідше: деривати із значенням найменування особи за дією (слухач, глядач, спостерігач і т. ін.), із значенням найменування об'єкту за дією (подразник, їда, питво), із значенням кількості дії (погляд, ковток).

Діеслова відчуття достатньо часто створюють акціональні парадигми, до яких входять дієслова з видовими значеннями, утворені за допомогою префіксів або суфіксів, і лексеми, що виражають додаткові семантичні модифікації (способи дії), наприклад: тиснути, втиснути, втискати, втискувати, затиснути, затискати, затискувати, натиснути, натискати, натискувати, стиснути, стискати, стискувати; защелити, прищелити, ущелити; чути, 
почути, почувати, учути (вчути), учувати (вчувати), дочути, дочувати, недочути, недочувати, відчути, відчувати; боліти, розболітися, розболюватися.

Більшість дієслів відчуття має конкретну семантику (наприклад: 'відчувати колір, світло (світлові хвилі)', 'відчувати звук (звукові хвилі), 'відчувати запах' тощо). Такі діеслівні лексеми, позначаючи конкретні відчуття (зорові відчуття, звукові відчуття, нюхові відчуття, відчуття болю, відчуття свербежу тощо), за своїми семантико-граматичними ознаками поєднуються у відповідні лексико-семантичні групи та підгрупи (наприклад: ЛСГ зорові дієслова; ЛСГ слухові дієслова; ЛСГ дотикові відчуття, підгрупи: тактильні дієслова, температурні дієслова, дієслова відчуття болю тощо).

Основу аналізованого ЛСП складають багатозначні дієслова (наприклад, чути, відчвати, почувати, слухати, дивитися, бачити, уллівати, боліти, пекти тощо), які входять до нього частіше за все в усіх своїх значеннях (ЛСВ). Усередині поля їх окремі ЛСВ $є$ компонентами однієї або різних лексико-семантичних груп. Так, діеслово чути у різних ЛСВ входить до ЛСГ слухові дієслова, ЛСГ нюхові дієслова, ЛСГ дотикові дієслова тощо. Семантичні структури дієслівних лексем перехрещуються в смисловому відношенні, тому спостерігається їх часткова інтерференція в межах ЛСП дієслів відчуття, а також проникнення до суміжних лексико-семантичних полів (ЛСП дієслова сприйняття, ЛСП дієслова бажання тощо).

Дієслова відчуття співвідносяться за такими семантичними моделями: «хтось зазнає (почуває) будь-яке відчуття» (Я відчув біль), «хтось / щось викликае в будь-кому те чи інше відчуття» (Приєлні пахощі викликали в мене відуття спокою. - Пахощі приєлно подразнювали ніздрi); «хтось має здатність сприймати зовнішній світ органами чуттів» (Я бачу світло); “щось є відчутним, сприйманим органами чуттів» (Почувався запах дилу).

Висновки... Отже, більшість діеслів відчуття являе собою активний фонд лексики, що зумовлюе складні, але закономірні взаємодії, зчеплення, перехрещення діеслівних лексем як у середині певної ЛСГ, так і з різними лексико-семантичними групами, які створюють ЛСП дієслів відчуття, а також з іншими лексико-семантичними полями. Не викликає сумніву взаємозв'язок дієслів відчуття із ЛСГ діеслів сприйняття, а також із дієсловами бажання, емощійного стану, емоційного переживання, емоційного відношення. Але ці зв'язки доволі складні, багато в чому залежать від внутрішніх семантичних об'єднань дієслів відчуття. 
Перспективи дослідження нами вбачаються у висвітленні питання про особливості фрункціонування дієслів відчуття, про парадигматичні відношення та синтагматичні зв'язки у межах цього лексикосемантичного поля.

\section{Список використаних джерел і літератури:} C. 118 .

1. Бондарко А. В. Принципы функциональной грамматики.Львов, 1983.

2. Булыгина Т. В. К построению типологии предикатов в русском языке.Семантические типы предикатов. Москва, 1982.

3. Грубор Д. Из книги «Видовые замечания». Вопросы глагольного вида. Москва, 1962. С. 75

4. Кильдибекова Т. А. Глаголы действия в современном русском языке: Опыт функционально-семантического анализа. Саратов: Изд-во Саратовского университета, 1985. $160 \mathrm{c.}$

5. Словник української мови: в 11 тт. / АН УРСР. Інститут мовознавства; за ред. І. К. Білодіда. Киӥв: Наукова думка, 1970-1980.

\section{References:}

1. Bondarko A. V. Principy' funkcional'noj grammatiki. L'vov, 1983. S. 118.

2. Buly'gina T. V. K postroeniyu tipologii predikatov v russkom yazy'ke. Semanticheskie tipy' predikatov. Moskva, 1982.

3. Grubor D. Iz knigi «Vidovy'e zamechaniya». Voprosy' glagol'nogo vida. Moskva, 1962. S. 75.

4. Kil'dibekova T. A. Glagoly' dejstviya v sovremennom russkom yazy'ke: Opy't funkcional'no-semanticheskogo analiza. Saratov: Izd-vo Saratovskogo universiteta, 1985. $160 \mathrm{~s}$.

5. Slovnyk ukrainskoi movy: v 11 tt. / AN URSR. Instytut movoznavstva; zared. I. K. Bilodida. Kyiv: Naukova dumka, 1970-1980.

\section{Summary \\ Natalia Ostratuik}

\section{Lexical-Semantic Sphere of Feeling Verbs in the Modern Ukrainian} Literary Language:the Semantic and Functional Characteristics

The article is devoted to the semantic and functional characteristics of feeling verbs lexical-semantic sphere in the modern Ukrainian literary language. It is noted that the positive semantic feature of thefeeling verbs of mental state is a feature of processuality.

According to the analysis of semanticcharacteristics, thefeeling verbsdo not have exact feature, and their semantic structure often contains positive semantic features, but no subjectivity.Most of them have no semaactivity, but the passivity of the content is not marked.

It is proved that the feeling verbs are used in syntactic constructions with the direct object - the name or objects of feeling. The feeling verbs do not have supplementary semantic components of the dynamic/static nature of action. 
The verbs of feeling are derived from frequency value abstract action in the word formation paradigm. They quite often create paradigm, which includes verbs with specific meanings formed with prefixes or suffixes and lexemes expressing additional semantic modification.

So, most of the feeling verbs are active fund of the vocabulary, which causes a natural interaction, the exchanging of verb lexemes. There is no doubt that the connection of feeling verb with lexical-semantic group of perception, desire and emotional distress ones is existed.

Key words: verb, feeling, sphere, semantics, lexeme, sema.

Дата надходження статті: «23» січня 2019 р.

Дата прийняття до друку: «28» лютого 2019 р.

\section{УДК 811.161.2'373.23}

DOI: 10.31475/fil.dys.2019.09.21

НАТАЛІЯ ПАВЛИКІВСЬКА, доктор фбілологічних наук, профбесор (л. Вінниия)

\section{Псевдонімія як антропонімна категорія}

У статті йдеться про украӥнські псевдоніли ХХ століття, зокрела про місие псевдонімів в антропонімійній систелі національної мови, історію вивчення псевдонілів, ббункціональне навантаження, вибір нолінативних оборл, мотиви та принципи псевдонілного найленування, ступінь інфборлативності.

Ключові слова: псевдоніл, фбункиіональне навантаження, нолінативна борла, мотиви, принципи, нолінація, інфборлативність.

Постановка проблели в загальнолу вигляді... Псевдоніми посідають важливе місце в антропонімійній системі національної мови, вони $e$ різновидом власних найменувань людей $i$ покликані приховувати їхне справжне ім'я або прізвище.

Аналіз досліджень $i$ публікацій... Мовне явище української псевдонімії розглядали такі вітчизняні лінгвісти як В. В. Німчук, П. П. Чучка, М. П. Лесюк, О. В. Петрова та слов'янської - Г. В. Суслова, О. В. Суперанська, В. А. Никонов, С. Вархол. Науковці акцентували увагу на проблемі лінгвістичного статусу псевдоніма, а також призначення, фрункції та номінації, на структурі класу псевдонімів тощо. Однак 